\section{AGREE: A BASIC program for assessing similarity in categorization judgments}

\author{
MALCOLM J. GRANT \\ Memorial University of Newfoundland \\ St. John's, Newfoundland, Canada
}

Consider a situation in which two subjects are independently confronted with a set of objects and are asked to sort them into meaningful categories. Each subject is free to use as many or as few categories as he/she wishes, and the number of objects assigned to each category need not be equal. It is clear that a comparison of the categories produced by the two subjects could potentially yield much useful information about how similar the subjects are in terms of the dimensions they consider relevant to the set of objects in question.

Social psychologists have long been interested in this kind of dimensional similarity between persons and particularly in the way such similarity relates to effective communication between the persons (see, e.g., Padgett \& Wolosin, 1980). The simple, unstructured categorization task described above has, however, rarely been used to assess cognitive similarity, perhaps because of a lack of awareness on the part of social psychologists of a number of useful similarity indexes that have recently been developed for use with categorization data (e.g., Brennan \& Light, 1974; Hubert, 1977; Popping, 1983). The work of Brennan and Light is particularly useful because, in addition to an index of agreement between two individuals, these authors provide a statistic that can be used to test the null hypothesis that agreement is no greater than would be expected by chance.

The measure of agreement developed by Brennan and Light (1974), although conceptually straightforward, is computationally complex. To encourage the use of this measure in cognitive-similarity research, an interactive program that performs the necessary computations is described.

Input. The user enters the data from either a video or a hard-copy terminal in response to prompts from the program. The items in each of the two subjects' categories are entered one after the other on separate lines. The last item in each category is followed by the keyword "END," and the keyword "ENDALL" informs the program that no further items remain to be entered for that subject.

Output. If the user wishes to check the accuracy of the data entered before computation begins, a listing of

The author wishes to thank Michael Rabinowitz for helpful advice concerning the implementation of AGREE on small computer systems. The author's mailing address is: Department of Psychology, Memorial University of Newfoundland, St. John's, Newfoundland, Canada A1B $3 \times 9$. the items in each category used by each subject may be requested. The contingency table frequencies can also be printed. The main computations in the program result in the printing of the observed number of agreements between the subjects (i.e., the number of times the subjects agree in sorting a pair of items into the same or different categories), the number of agreements that would be expected on the basis of chance, the variance of the agreement statistic, and the value of $Z$ for testing the null hypothesis.

Language and Computer. The 175-line program is written in BASIC for a VAX 11-780 computer. Current dimensions allow up to 20 categories per subject and up to 25 objects per category. A reduction in these dimensions would be necessary to implement the program on a system with less than $48 \mathrm{~K}$ of memory.

The version of BASIC used on the VAX 11-780 has certain features that may not be common to other versions. For example, variable names of up to six characters have been used and may need to be shortened on systems in which this is not permitted. Another feature that may not be available on some systems is the FORUNTIL statement. These statements have been used in AGREE primarily to facilitate data entry. They can, however, easily be replaced by additional input statements in which the user specifies the number and size of each subject's categories in advance. Other nonstandard features used in AGREE, such as lines with multiple statements separated by back slashes, are relatively minor and in most cases can be dealt with by routine editing.

Example. In the hypothetical example that follows, three subjects, $A, B$, and $C$, have been asked to sort 10 countries into meaningful categories. The results are shown in Table 1. A uses four categories, B uses three categories, and $C$ uses six categories. Successive pairwise comparisons of these sorting schemes using AGREE produce the statistics shown in Table 2. A and C show

Table 1

Sorting Schemes Used by Three Hypothetical Subjects $(A, B$, and $C)$

\begin{tabular}{|c|c|c|c|c|c|}
\hline \multicolumn{6}{|c|}{ A's Sorting Scheme } \\
\hline & $\begin{array}{l}\text { Sweden } \\
\text { Britain }\end{array}$ & $\begin{array}{l}\text { Belgium } \\
\text { France }\end{array}$ & $\begin{array}{l}\text { USSR } \\
\text { Hungary } \\
\text { Poland }\end{array}$ & $\begin{array}{l}\text { Egypt } \\
\text { Italy } \\
\text { Spain }\end{array}$ & \\
\hline \multicolumn{6}{|c|}{ B's Sorting Scheme } \\
\hline & $\begin{array}{l}\text { USSR } \\
\text { Egypt } \\
\text { France }\end{array}$ & $\begin{array}{l}\text { Spain } \\
\text { Sweden } \\
\text { Poland } \\
\text { Italy }\end{array}$ & $\begin{array}{l}\text { Britain } \\
\text { Hungary } \\
\text { Belgium }\end{array}$ & & \\
\hline \multicolumn{6}{|c|}{ C's Sorting Scheme } \\
\hline USSR & Sweden & Egypt & $\begin{array}{l}\text { Spain } \\
\text { Italy }\end{array}$ & $\begin{array}{l}\text { Hungary } \\
\text { Poland }\end{array}$ & $\begin{array}{l}\text { Britain } \\
\text { France } \\
\text { Belgium }\end{array}$ \\
\hline
\end{tabular}


Table 2 Comparison Statistics for Subjects A, B, and C

\begin{tabular}{|c|c|c|c|c|}
\hline Subjects & $\begin{array}{l}\text { Number of } \\
\text { Agreements }\end{array}$ & $\begin{array}{l}\text { Agreements } \\
\text { Expected } \\
\text { by Chance }\end{array}$ & Variance & $\mathrm{Z}$ \\
\hline$A$ and $B$ & 27 & 29.27 & 6.14 & -0.91 \\
\hline$A$ and $C$ & 38 & 33.78 & 2.75 & 2.54 \\
\hline$B$ and $C$ & 32 & 30.67 & 3.69 & 0.69 \\
\hline
\end{tabular}

significant agreement with each other in the categories they use, but neither shows greater agreement with $B$ than would be expected by chance.

Availability. A complete listing of AGREE and instructions for use are available without charge. Send requests to Malcolm J. Grant, Department of Psychology,
Memorial University of Newfoundland, St. John's, Newfoundland, Canada A1B 3X9.

\section{REFERENCES}

Brennan, R. L., \& Light, R. J. Measuring agreement when two observers classify people into categories not defined in advance. British Journal of Mathematical and Statistical Psychology, 1974, 27, 154-163.

HUBE RT, L. J. Nominal scale response agreement as a generalized correlation. British Journal of Mathematical and Statistical Psy. chology, 1977, 30, 98-103.

PAdGetT, V. R., \& Wolosin, R. J. Cognitive similarity in dyadic communication. Journal of Personality and Social Psychology, 1980, 39, 654-659.

PopPING, R. Traces of agreement: On the DOT-product as a coefficient of agreement. Quantity and Quality, 1983, 17, 1-18.

(Revision accepted for publication October 26, 1983.) 